\title{
Jenis - Jenis Burung yang Diperjual-Belikan di Pasar Burung Palembang Sumatera Selatan
}

\author{
Dian Mutiara ${ }^{1}$, Syamsul Rizal ${ }^{2 *}$, Muhammad Royan $^{3}$ \\ *e-mail: syamsul_rizal_msi@yahoo.com \\ ${ }^{1,2}$ Program Studi Biologi, Fakultas Matematika dan Ilmu Pengetahuan Alam \\ Universitas PGRI Palembang \\ ${ }^{3}$ Alumni Program Studi Biologi, Fakulti Fakultas Matematika dan Ilmu Pengetahuan Alam \\ Universitas PGRI Palembang
}

\begin{abstract}
Research on the types of orders of Passeriformes that have been traded at the Palembang bird market in South Sumatra has been carried out. The aim of this study was to find out the types of Passeriformes sequences, including endemic birds, protected birds and endangered Sumatran birds that were traded at the Palembang bird market. South Sumatra. This research was conducted in January-April 2019, at the bird market on the old Masjid Jalan, Kelurahan 17 Ilir and Pasar Cinde on Jalan Jendral Sudirman. The method used is purposive sampling. Bird identification was carried out at the Biology Laboratory, Faculty of Mathematics and Natural Sciences, University of PGRI Palembang. The types of Order Passers found were 12 Familia, 23 Genus, and 31 Species. Familia Sturnidae which has the highest diversity of species, namely 5 species.
\end{abstract}

Keywords: aves, passeriformes, identification, species.

\begin{abstract}
ABSTRAK
Telah dilakukan penelitian jenis-jenis burung ordo Passeriformes yang diperjualbelikan di pasar burung Palembang Sumatera Selatan, penelitian bertujuan untuk mengetahui jenis-jenis burung ordo Passeriformes, termasuk burung endemik, burung dilindungi dan burung Sumatera terancam punah yang diperjual-belikan di pasar burung Palembang Sumatera Selatan. Penelitian dilaksanakan pada bulan JanuariApril 2019, di pasar burung di Jalan Masjid lama, Kelurahan 17 Ilir, Kecamatan Ilir Timur 1 dan pasar Cinde di jalan Jendral Sudirman. Metode yang digunakan purposive sampling. Identifikasi burung dilakukan di Laboratorium Biologi, Fakultas Matematika dan Ilmu Pengetahuan Alam Universitas PGRI Palembang. Jenis-jenis burung Ordo Passeriformes yang ditemukan terdiri dari 12 Familia, 23 Genus, dan 31 Species. Familia Sturnidae yang mempunyai keragaman species yang paling tinggi yaitu 5 species.
\end{abstract}

Kata Kunci: aves, passeriformes, identifikasi, species.

\section{PENDAHULUAN}

Indonesia salah satu negara yang berada di wilayah tropis merupakan negara yang mempunyai keanekaragaman fauna yang tinggi. Salah satu jenis faunahya adalah burung. Terdapat lebih kurang 9.040 jenis burung di dunia, 1.531 jenis diantaranya terdapat di Indonesia dengan 397 jenis berstatus endemik (Sulistyadi, 2010). Safanah (2013), menyebutkan sebanyak 372 jenis burung 
yang ada di indonesia merupakan jenis burung endemik dan 149 jenis adalah burung migran. Di kepulauan Sumatera terdapat keanekaragaman burung-burung pekicau yang menyebar diberbagai tipetipe habitat. Sumatera Selatan yang memiliki hutan, pegunungan dan pantai merupakan habitat burung baik endemk maupun burung burung migran. Hutan memberikan fasilitas bagi burung sebagai tempat bersarang, istirahat, berbiak, dan mencari makan (Ayat, 2011).

Burung memiliki kepentingan ekonomi karena sebagian dari jenis burung dapat dijadikan sebagai hewan peliharaan dan hewan ternak yang dapat diperdagangkan hingga bernilai ekonomi tinggi. Burung juga dapat dijadikan sumber bahan makanan karena mengandung protein yang tinggi. Burung-burung pekicau yang terdapat di Palembang berasal dari kawasan Sumatera Selatan biasanya merupakan hasil buruan yang kemudian diperjualbelikan di pasar burung Palembang. Terdapat dua lokasi yang terjadi transaksi jual beli burung pekicau yang bernilai ekonomi yaitu pasar burung yang beralamat di jalan Masjid Lama, Kelurahan 17 ilir, Kecamatan Ilir Timur 1, dan Pasar Cinde di jalan Jendral Sudirman.

Secara ilmiah burung pekicau merupakan kerabat ordo Passeriformes dengan ciri umum badan relatif kecil, warna beragam, memiliki empat jari satu mengarah kebelakang dan tiga mengarah ke depan. Ciri morfologi lainnya memiliki bulu ekor yang kaku sebagai penyeimbang ketika bertengger, seperti burung Murai Batu (Copsychus malabaricus). Murai Batu adalah anggota familia Turdidae, Turdidae memiliki kemampuan berkicau dengan vokal suara yang sangat menarik, merdu, dan bervariasi sehingga burung ini menjadi daya tarik masyarakat dan menjadikan hewan peliharaan di rumah (Agung. dkk,. 2016). Selain itu, ada pula beberapa jenis burung pekicau yang diperjual-belikan di pasar burung, seperti Srigunting Sumatera (Dicrurus sumatranus) familia Dicruridae, Kutilang (Pycnonotus aurigaster) familia Pycnonotidae, Tiung Emas (Gracula religiosa) familia Sturnidae, dan berbagai jenis burung pekicau lainnya.

Selama ini belum ada penelitian yang melaporkan tentang jenis-jenis burung pekicau yang diperjual-belikan di kota Palembang, maka perlu dilakukan penelitian mengenai jenis-jenis burung pekicau ordo Passeriformes yang diperjual-belikan di pasar burung Palembang Sumatera Selatan.

\section{BAHAN DAN METODE Tempat dan Waktu Penelitian}

Penelitian dilaksanakan pada bulan Januari sampai dengan bulan April 2019. Lokasi pertama dipasar burung Jalan Masjid lama, Kelurahan 17 Ilir, Kecamatan Ilir Timur 1, lokasi kedua yaitu pasar Cinde di jalan Jendral Sudirman. Identifikasi burung dilakukan di Laboratorium Biologi, Fakultas MIPA Universitas PGRI Palembang.

\section{Alat dan Bahan}

Alat-alat yang digunakan dalam penelitian adalah kamera $13 \mathrm{MP}$, alatalat tulis dan Buku Panduan Lapangan Burung-burung di Sumatera, Jawa, Bali, dan Kalimantan menurut MacKinnon, 2010 .

\section{Cara Kerja \\ Survey Lapangan}

Survey dilakukan untuk mengetahui lokasi pasar burung yang berada di Palembang Sumatera Selatan. Didapatkan dua lokasi yaitu : Di Pasar Burung yang beralamat di Jalan Masjid lama, Kelurahan 17 Ilir, Kecamatan Ilir Timur 1 (lokasi pertama). Lokasi pertama dibuka setiap hari minggu pada pukul 08:00 s/d 15:00 WIB dan lokasi kedua di pasar Cinde jalan Jenderal Sudirman, 
yang dibuka pada hari minggu pada pukul : 07:00 s/d 17:00 WIB.

\section{Pembuatan Kunci Determinasi}

Deskripsi disusun untuk membuat kunci determinasi. Setiap burung ordo Passeriformes yang ditemui dicatat ciricirinya kemudian diidentifikasi dengan Buku Panduan Burung-burung di Sumatera, Jawa, Bali, dan Kalimantan, (MacKinnon, 2010) yang sudah dimodifikasi.

\section{Identifikasi Burung}

Burung-burung ordo Passeriformes yang telah diperoleh selama pengamatan diidentifikasi berdasarkan morfologi menurut Buku Panduan Lapangan Burung-burung di Sumatera, Jawa, Bali, dan Kalimantan (MacKinnon, 2010), yang dilihat dari karakteristik bulu, warna bulu dan morfologi dari bentuk tubuh, bentuk paruh, bentuk kaki, bentuk ekor. Kemudian dicocokkan dengan kunci determinasi. Data di analisis secara deskriptif untuk mendapatkan kesimpulan.

\section{HASIL DAN PEMBAHASAN}

Hasil identifikasi burung ordo Passeriformes yang diperjual-belikan di pasar burung Palembang Sumatera Selatan terdiri dari 12 Familia, 23 Genus dan 31 Species. Diketahui burung dengan status dilindungi yang ditemukan dalam pengamatan seperti burung Cica-Daun Besar, Cica-Daun sayap Biru, Poksay Jambul, Tiong Emas, Tangkar Ongklet, Tangkar, dan Ekek Layongan.

Burung ordo Passeriformes memiliki ciri-ciri yaitu mempunyai kaki relatif pendek, tiga jari kedepan dan satu ke belakang, Memiliki ekor yang kaku sebagai penyeimbang ketika bertengger, Ukuran tubuh relatif lebih kecil dibandingkan burung-burung dalam ordo lainnya, Dibagi dua bagian burung penyanyi dan bukan penyanyi (Munaf, 2006). Aves adalah salah satu jenis satwa yang sangat terpengaruh keberadaannya akibat perubahan habitat secara alami dan alih fungsi lahan hutan, hilangnya pohon hutan dan tumbuhan semak, menyebabkan hilangnya tempat bersarang, berlindung dan mencari makan berbagai jenis burung. Sementara, burung memiliki peran penting dalam ekosistem antara lain sebagai penyerbuk, pemencar biji, pengendali hama. Burung juga seringkali digemari oleh sebagian orang dari suara dan keindahan bulunya (Ayat, 2011).

Dari hasil pengamatan yang dilakukan terdapat 12 familia, 23 genus dan 31 species, burung yang paling sedikit atau jarang terlihat di lokasi pasar burung ialah burung Srigunting Sumatera (Dicrurus sumatranus), Kumbang Padi (Niltava grandis), dan Tangkar Centrong (Crypsirina temia). Burung dengan species yang paling banyak ditemukan di pasar burung adalah dari familia Sturnidae dengan ciri-ciri paruh kuat, tajam, lurus, dan tungkai kaki panjang seperti Acridotheres javanicus (Jalak Kerbau). Burung yang diperjual-belikan di pasar burung Palembang mempunyai perannya masing-masing terutama dari vokal suara yang menarik dan keindahan bulunya sehingga masyarakat tertarik untuk membeli burung tersebut, terutama burung yang paling dominan yang disukai oleh para pembeli ialah seperti burung Murai Batu (Cophsycus malabaricus) burung ini berasal dari kawasan pulau Sumatera (termasuk pulau-pulau disekitarnya) dan Kalimantan (termasuk pulau-pulau disekitarnya) cukup umum terdapat di dataran rendah, sampai ketinggian 1.500 $\mathrm{m}$ di beberapa tempat. Burung dengan ciri-ciri berukuran tubuh sedang, mempunyai warna bervariasi, berkepala bulat dengan kaki agak panjang, paruh ramping tajam, dan bersayap lebar yang 
dikelompokkan kedalam familia masyarakat menjadikan burung ini Turdidae. Murai Batu ini memiliki sebagai ajang kontes kicauan burung kemampuan berkicau dengan vokal suara (Agung, 2016) dan bebarapa burung yang sangat menarik, merdu, sehingga perkicau lainnya.

Tabel 1. Jenis-jenis burung ordo Passeriformes yang didapat di dua lokasi pasar burung Palembang Sumatera Selatan.

\begin{tabular}{|c|c|c|c|c|c|}
\hline No. & Ordo & Familia & Genus & Spesies & Nama Lokal \\
\hline 1 & Passeriformes & Dicruridae & Dicrurus & Dicrurus sumatranus & Srigunting Sumatera \\
\hline 2 & & Chloropseidae & Chloropsis & $\begin{array}{l}\text { Chloropsis } \\
\text { cochinchinensis }\end{array}$ & Cica daun sayap Biru \\
\hline 3 & & & & Chloropsis sonnerati & Cica daun Besar \\
\hline 4 & & Fringillidae & Serinus & Serinus canaria & Kenari \\
\hline 5 & & Timaliidae & Garrulax & Garrulax leucolophus & Poksai Jambul \\
\hline 6 & & & & Garrulax lugubris & Poksai Hitam \\
\hline 7 & & & & Garrulax mitratus & Poksai Genting \\
\hline 8 & & Pycnonotidae & Pycnonotus & $\begin{array}{l}\text { Pycnonotus } \\
\text { aurigaster }\end{array}$ & Cucak Kutilang \\
\hline 9 & & & & $\begin{array}{l}\text { Pycnonotus } \\
\text { melanicterus }\end{array}$ & Cucak Kuning \\
\hline 10 & & & & Pycnonotus atriceps & Cucak Kuricang \\
\hline 11 & & & Alophoixus & Alophoixus bres & Empuloh Janggut \\
\hline 12 & & Silviidae & Cisticola & Cisticola juncidis & Cici Padi \\
\hline 13 & & & Lacustella & Lacustella lanceolata & Kecici Lurik \\
\hline 14 & & & Prinia & Prinia familiaris & Perenjak Jawa \\
\hline 15 & & Muscicapidae & Niltava & Niltava grandis & Kumbang Padi \\
\hline 16 & & Sturnidae & Sturnus & Sturnus melanopterus & Jalak Putih \\
\hline 17 & & & & Sturnus contra & Jalak Suren \\
\hline 18 & & & Acridotheres & $\begin{array}{l}\text { Acridotheres } \\
\text { javanicus }\end{array}$ & Jalak Kerbau \\
\hline 19 & & & Aplonis & Aplonis panayensis & Perling Kumbang \\
\hline 20 & & & Gracula & Gracula religiosa & Tiung Emas \\
\hline 21 & & Turdidae & Zoothera & Zoothera interpres & Anis Kembang \\
\hline 22 & & & Myophonus & $\begin{array}{l}\text { Myophonus } \\
\text { melanurus }\end{array}$ & Ciung-batu Sumatera \\
\hline 23 & & & Copsychus & $\begin{array}{l}\text { Copsychus } \\
\text { malabaricus }\end{array}$ & Murai Batu \\
\hline 24 & & & & Copysychus saularis & Kacer \\
\hline 25 & & Campephagidae & Pericrocotus & Pericrocotus solaris & Sepah Dagu Kelabu \\
\hline 26 & & & & $\begin{array}{l}\text { Pericrocotus } \\
\text { flammeus }\end{array}$ & Sepah Hutan \\
\hline 27 & & Oriolidae & Oriolus & Oriolus chinensis & $\begin{array}{l}\text { Kepudang kuduk- } \\
\text { Hitam }\end{array}$ \\
\hline 28 & & & Irena & Irena puella & Kecambang Gadung \\
\hline 29 & & Corvidae & Platylophus & $\begin{array}{l}\text { Platylophus } \\
\text { galericulatus }\end{array}$ & Tangkar Ongklet \\
\hline 30 & & & Crypsirina & Crypsirina temia & Tangkar Cetrong \\
\hline 31 & & & Cissa & Cissa chinensis & Ekek Layongan \\
\hline
\end{tabular}

Dari 31 species burung yang teridentifikasi terdapat beberapa species langka serta species dilindungi menurut peraturan menteri lingkungan hidup dan kehutanan Republik Indonesia UU Nomor P.20/Menlhk/Sekjen/Kum.1/6/2018, dalam (http://www.jalaksuren.net) seperti 
burung Jalak Putih (Sturnus melanopterus) dari familia Sturnidae dengan ciri-ciri ukuran tubuh $18-25 \mathrm{~cm}$, mempunyai kaki yang panjang, paruh kuat, tajam dan burung endemik di Jawa, Bali, dan Lombok. Kebiasaannya yang hidup berpasangan atau dalam berkelompok, mencari makan di tanah terbuka (MacKinnon,2010). Selain itu, burung dengan status dilindungi lainnya yang dijumpai dalam pengamatan seperti burung Cica-Daun Besar (Chloropsis sonnerati), Cica-Daun sayap Biru (Chloropsis cochinchinensis) familia Chloropsidae, Poksay Jambul (Garrulax leucolophus) dari familia Timaliidae, familia Corvidae seperti Tangkar Ongklet (Platylophus galericulatus), Tangkar Centrong (Crypsirina temia), Ekek Layongan (Cissa chinensis) dan Tiong Emas (Gracula religiosa) dari familia Turdidae. Selain burung yang dilindungi, adapula burung yang dikeluarkan dari daftar burung dilindungi menurut Peraturan Menteri Lingkungan Hidup dan Kehutanan No. 92/2018 yang merupakan perubahan atas PermenLHK No. 20/2018, dalam (https://sainkompas.com) seperti Kucica Hutan atau Murai Batu (Copsychus malabaricus), Jalak Suren (Sturnus contra) yang juga ditemukan dalam penelitian.

Menurut MacKinnon (2010), Burung endemik yang berasal dari pulau Sumatera yang teridentifikasi adalah Srigunting Sumatera (Dicrurus sumatranus), Poksay Jambul (Garrulax leucolophus), Perenjak Jawa (Prinia familiaris), Kumbang Padi (Niltava grandis), dan Ciung-batu Sumatera (Myophonus melanurus). Dan burung Sumatera langka dalam kategori terancam punah seperti Srigunting Sumatera (Dicrurus sumatranus) dan Ciung-batu Sumatera (Myophonus melanurus) menurut daftar merah Internasional Union for Conservation of Nature (IUCN), dalam (https://www.alamendah.org) Redlist berstatuskan Near Threatened atau hampir terancam. Burung tersebut termasuk didaftar jenis-jenis burung yang diperjual-belikan di pasar burung Palembang yang dijumpai selama pengamatan.

Burung dengan status dilindungi biasanya dalam ketegori dengan beberapa hal yang menjadi gangguan dan ancaman terhadap keberadaan berbagai spesies burung di hutan lindung ini, yaitu perburuan liar yang dilakukan masyarakat untuk dipelihara sebagai burung hias ataupun dikomersilkan. Selain itu, perubahan penggunaan lahan hutan menjadi lahan perkebunan yang dilakukan masyarakat semakin menekan keberadaan burung, serta membuat burung sulit memperoleh pakan karena pola tanaman yang homogen. Ada dua faktor yang mempengaruhi habitat burung yang pertama gangguan tidak langsung adalah perubahan atau modifikasi lingkungan alami oleh manusia menjadi lahan pertanian, kebun, perkotaan, jalan raya, dan industri, dan gangguan langsung terhadap burung yaitu dengan membunuh burung untuk bahan makanan, bulu, minyak, dan olahraga berburu (Kiki., dkk. 2017).

Menurut Husodo (2017), burung digolongkan kedalam kategori dilindungi berdasarkan beberapa alasan, yaitu: mempunyai populasi yang kecil, adanya penurunan yang tajam pada jumlah individunya di alam, maupun memiliki daerah penyebaran yang terbatas. Untuk menghindari itu biasanya masyarakat menangkar burung-burung ini dirumah kemudian diperkembang-biakan agar species alami tidak terganggu dan tidak terancam dari kepunahan.

Burung dari familia Pycnonotidae merupakan burung yang mempunyai penyebaran yang cukup luas di Sumatera karena kemampuan adaptasinya terhadap lingkungan yang sangat tinggi dan sifat makannya yang di samping memakan serangga juga dapat mengkonsumsi buah- 
buahan dari tumbuhan lokal yang umum dijumpai di Sumatera (MacKinnon, 2010). Selain itu, dilihat dari status endemisitasnya, ada satu jenis yang merupakan endemik pulau Sumatera dengan burung yang memiliki frekuensi relatif tertinggi yaitu Perenjak Jawa (Prinia familiaris), Safanah (2017). Burung Perenjak Jawa biasa ditemukan di tempat terbuka atau daerah bersemak di taman, pekarangan, tepi sawah, hutan sekunder, hingga ke hutan bakau. Dari indeks keanekaragaman membuktikan bahwa kekayaan hayati dalam suatu kawasan didukung secara penuh oleh kondisi ekologis disekelilingnya, mulai dari aktivitas makhluk hidup lain yang hidup secara berdampingan, ketersediaan makanan, keberadaan predator, hingga ketersediaan tempat tinggal yang aman dan nyaman untuk burung tersebut hingga dapat berkembang biak (Hariyanto., $d k k$ 2012).

Dari pengamatan bahwa ditemukan species burung yang bernilai ekonomi tinggi yaitu Poksai Jambul (Garrulax leucolophus) familia Timaliidae dengan ciri-ciri tubuh besar, bersayap pendek, dan bukan penerbang yang kuat, burung ini termasuk dalam status burung yang dilindungi menurut peraturan UU Nomor P.20/Menlhk/Sekjen/Kum.1/6/2018

dalam (http://www.jalaksuren.net), Harga burung Poksai Jambul bisa mencapai 3 juta rupiah. Burung ini memiliki ciri-ciri berwarna hitam kecoklatan, kepala putih dengan topeng hitam dengan jambul sedikit tegak, setrip mata hitam menurun. Dalam penyebaran Global burung Poksay Jambul tersebar diantara wilayah Himalaya, Asia tenggara (kecuali di Semenanjung Malaysia) dan Sumatera (MacKinnon,2010). Populasinya mulai menurun akibat dari penangkapan dan perburuan liar yang sulit terkendali yang dapat mengancam keberadaan species burung tesebut. Di pasar burung Palembang ada beberapa species burung yang diperjual-belikan dengan nilai ekonomi tinggi lainnya, seperti burung Murai Batu (Copsychus malabaricus) harga lokal mulai dari 3 juta-10 juta untuk usia 10 minggu dan 3 minggu berharga mencapai 2,9 juta - 2,3 juta, Jalak (dari familia sturnidae) dengan harga bervariasi sekitar Rp.340.000, Rp.410.000, Rp.140.000, Rp.530.000, Srigunting (dari familia dicruridae) dengan harga Rp.150.000 - Rp.250.000, dan burung-burung kicauan lainnya yang dijual dengan harga dimulai dari Rp.150.000/ekor.

Besarnya jumlah penduduk dan meningkatnya tekanan eksploitasi terhadap semua sumber daya yang memiliki nilai ekonomi, maka tidak dapat dihindarkan bahwa alam berada dalam status kemunduran. Hutan didesak sampai ke puncak gunung yang paling tinggi, burung-burung diburu untuk dimakan, untuk olaraga, atau dijual (MacKinnon, 2010). Seharusnya lokasi pasar burung memiliki nilai konservasi yang cukup penting bagi burung, hal ini terlihat dari ditemukannya beberapa jenis burung yang langka dan dilindungi berdasarkan peraturan menteri lingkungan hidup dan kehutanan Republik Indonesia.

Keberadaan burung lambat laun akan semakin menurun apabila tidak dilakukan upaya konservasi, ditambah lagi dengan masih banyaknya burungburung yang dilindung keberadaannya. Menurunnya keanekaragaman spesies burung terjadi karena berkurangnya sumber pakan, tempat berlindung serta bersarang, dengan keadaan yang seperti ini membuat burung semakin tertekan didalam habitatnya. Suatu spesies burung biasanya memerlukan kondisi lingkungan dan spesies makanan yang spesifik (Hadinoto, 2012). Karena besarnya jumlah penduduk dan meningkatnya tekanan eksploitasi terhadap semua sumber daya yang memiliki nilai ekonomi, maka tidak dapat dihindarkan 
bahwa alam berada dalam sistem kemunduran, sistem kawasan konservasi di Sumatera tidak merata (MacKinnon, 2010).

Secara teori, keanekaragaman jenis burung dapat mencerminkan tingginya keanekaragaman hayati hidupan liar lainnya, artinya burung dapat dijadikan sebagai indikator kualitas hutan. Berbagai jenis burung dapat kita jumpai di berbagai tipe habitat, diantaranya hutan (primer/sekunder), perkebunan (sawit/ karet/kopi) dan tempat terbuka (pekarangan, sawah, lahan terlantar). kawasan hutan di Sumatera mempunyai nilai penting dan berpotensi sebagai habitat berbagai keanekaragaman hayati, terutama potensi keanekaragaman jenis burung (Ayat, 2011).

Beberapa jenis burung yang diperdagangkan untuk menjadi bahan pangan (konsumsi daging, hobi pemeliharaan, pengobatan, dan olaraga). Adanya permintaan burung oleh masyarakat menjadi suatu peluang pasar bagi pedagang dan penangkap burung untuk mendapatkan keuntungan secara ekonomi. Maka, pemberian status dilindung merupakan upaya untuk mencegah terjadinya kepunahan sehingga dapat mempertahankan keberadaan jenis burung tersebut di alam. Keanekaragaman jenis burung merupakan indikator kondisi suatu habitat. Keberadaan burung sangat berpengaruh terhadap kondisi ekosistem tersebut dapat dikatakan baik atau tidak bagi makhluk hidup yang ada di dalamnya (Maya. $d k k$. 2016). Masyarakat yang memiliki pengetahuan dan persepsi mengenai batasan atau toleransi dalam pemanfaatan satwa cenderung menciptakan sikap konservatif dari masyarakat terhadap satwa. Hal ini menunjukan bahwa masyarakat lebih menjaga keberadaan suatu jenis satwa dengan tidak menangkapnya dan harus ada jumlah batasan satwa yang ditangkap untuk dimanfaatkan (Kuspriyangga, 2013).

Memelihara burung di Indonesia telah menjadi budaya yang sangat sulit dihilangkan, kegiatan ini tidak hanya terjadi di kota kecil tetapi juga terjadi di perkotaan. Masyarakat meyakini bahwa dengan memilihara burung rejeki akan lebih lancar. Dalam kegiatan ini diketahui banyak pihak yang bermain serta tersusun oleh jaringan yang sangat memungkinkan untuk berkembangannya pendistribusian didaerah atau kaitannya dengan perdagangan satwa yang sebenarnya menjadi permasalahan utama dalam upaya konservasi jenis burung (Alves., $d k k$ 2013).

\section{KESIMPULAN}

Jenis-jenis burung ordo Passeriformes yang ditemukan terdiri dari 12 Familia, 23 Genus, dan 31 Species. Familia Sturnidae yang mempunyai keragaman species yang paling tinggi yaitu 5 species.

\section{DAFTAR PUSTAKA}

Agung Dwi Saputro. (2016). "Perilaku burung murai batu (Copsychus malabaricus) siap produksi", Jurnal Ilmiah Peternakan Terpadu. Vol. 4(3).

Alves, R. R., Leite, R. C. L., Silva, W. M., Dandara, M. M. B. (2013). Ethno-ornithology and conservation of wild birds in the semi-arid caatinga of northeastern Brazil. Journal of Ethnobiology and Ethnomedicine 9:14.

Ayat, A. (2011). Buku Panduan Lapangan Burung-burung Agroforest di Sumatera. ICRAF Asia Tenggara. Bogor.

Hadinoto, Mulyadi, A. dan Siregar, Y.I. (2012). Keanekaragaman Jenis Burung Di Hutan Kota Pekanbaru. Jurnal Ilmu Lingkungan 6(1): 25-42. 
Hariyanto S., Irawan B., Hening S. (2012). Keanekaragaman jenis burung pada berbagai tipe pemanfaatan lahan di kawasan muara kali lamong, perbatasan surabaya-gresik. Jurnal Hayati: 17 (131-138.

Husodo T, Partasasmita R, Atsuary ZIA. (2017). Penggunaan kanopi hutan oleh berbagai species burung di zona montana hutan tropis, cagar alam gunung tilu, jawa barat, Indonesia. Biodiversitas 18: (453457).

Kiki D. A., Agus S, Jani M. (2017). Keanekaragaman species burung di hutan lindung register 25 Pematang Tanggang Kabupaten Tanggamu Lampung. Jurnal Sylva Lestari: Vol. 5 No.1, (105-116).

Kuspriyangga, A. 2013. Ernoornitologi Burung Kancilan Flores Pada Masrakat Lio Di Taman Nasional Kelimutu. Departemen Konservasi Sumberdaya Hutan Dan Ekowisata Fakultas Kehutanan. Institut Pertanian. Bogor.

MacKinnon J., K. Philips dan B. Van Balen. (2010). Burung-burung di Sumatera, Jawa, Bali, dan Kalimantan. Puslitbang BiologiLIPI. Bogor.

Maya A., Sugeng P. H., dan Nuning N. (2016).Keanekaragaman jenis burung di hutan rakyat pekon kelungu kecamatan kota agung kabupaten tanggamus. Jurnal Sylva Lestari: Vol. 4 No. 2, (5160)

Munaf, Herman. (2006). Taksonomi Vertebrata. Padang: Universitas Padang.

Peraturan menteri lingkungan hidup dan kehutanan Republik Indonesia UU NOMOR P.20 / MENLHK / SETJEN

KUM.1/6/2018.Dalam $\underline{\text { Htps://ww }}$ w.jalaksuren.net/daftar-burung-di- indonesia-yang-dilindungiundang- undang/ Di akses tanggal 1 Juli 2019.

Safanah N.G, Nugraha CS, Partasasmita P,Husodo T. (2017). Keanekaragaman jenis burung di Taman Wisata Alam dan Cagar Alam Pananjung Pangandaran, Jawa Barat. Biodiversitas 3: 266272.

Https.//sainkompas.com//read/2018/10/19 /cucak rawa-dan-4-jenis-burungtak-lagi-dilindungi-kontroversimencuat/. Diakses tanggal 02 Juli 2019

Https.//www.alamendah.org//read2014/0 8/14/daftar-dan-gambar-burunglangka Sumatera/. Di Akses tanggal 05 Juli 2019. 